\title{
Federal Punishment and the Legal Time of Bleeding Kansas
}

During a March 2009 college basketball game between the Kansas Jayhawks and the Missouri Tigers, Kansas University students unfurled a large banner-a reprint of the mural painted by John Steuart Curry on the walls of the Kansas state capitol between 1937 and 1942. The banner of the Kansas students taunts the Missouri Tigers by merging Jayhawk Nation's victory in the game with their triumph in the war over slavery during Bleeding Kansas. In this version, John Brown's Bible has been replaced with a trophy representing the 2008 NCAA National Championship win of the Kansas Jayhawks. This use of the banner represents the proslavery loss in the war at the Kansas-Missouri border, which began in 1854 and marked the beginning of the national Civil War. Brown was at the center of this war, coming to Kansas in 1854 to join his five sons, who were already imagining the illegality of slavery in Kansas. By posing as a land surveyor, Brown passed through the proslavery blockades at the territory's borders. He refused to recognize the laws of slavery in a moment when two territorial governments claimed jurisdiction in Kansas Territory and when federal law conspired with the proslavery government to establish the institution of slavery in Kansas. As part of abolition Kansas, Brown disobeyed federal and territorial law to imagine new terrains of freedom. His stance in the mural, with his arms outstretched like Moses parting the Red Sea, reflected the way he came to stand in for the realization of the impossible. Jayhawk Nation's commemoration of Bleeding Kansas is part of a larger cultural remembrance that takes place in sports and politics, in classrooms and field trips, in state memorials and museum exhibits, and during stories over family dinners. What is forgotten in these moments of recollection is that Bleeding Kansas was fundamentally about slavery's relationship to law and order. 


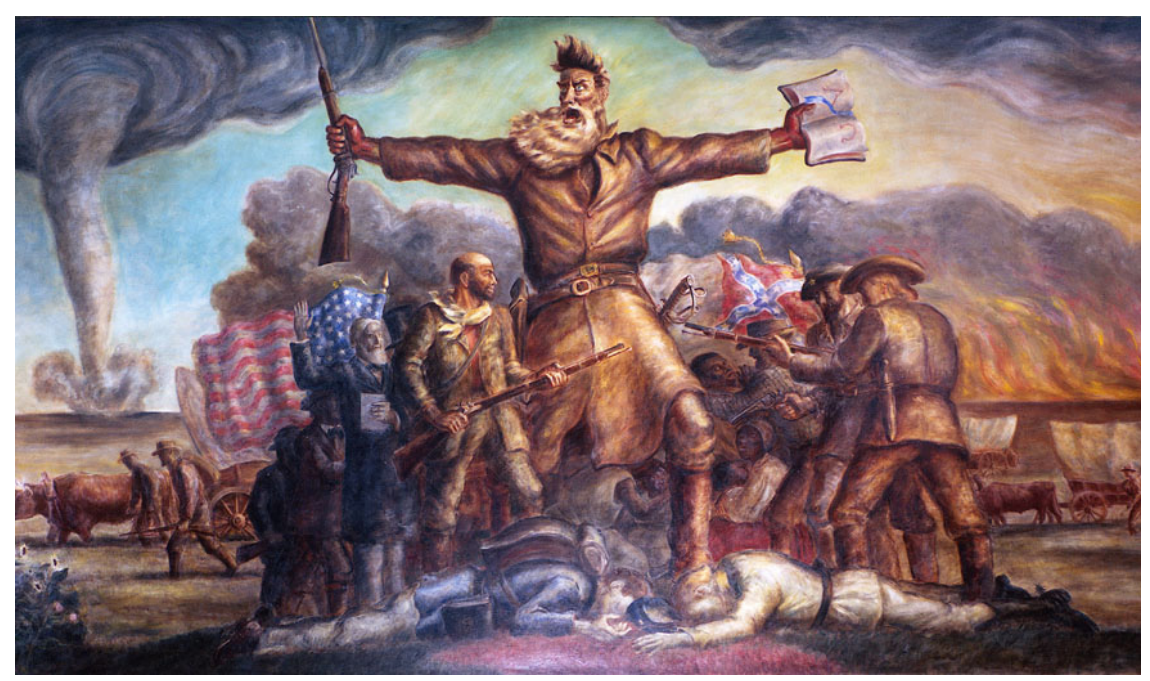

FIGURE 7. John Steuart Curry, Tragic Prelude, 1940.

Brown's position in the mural, between proslavery and union forces, reflected this claim to an alternative practice of law, a legal tradition that emerged in an environment where federal control was a symbol of slavery. Bleeding Kansas was therefore a different kind of legal moment, one in which John Brown and many others created the idea of abolition Kansas, a place in which "the people" refused to recognize the foreign law of slavery. After the 1854 territorial election, when crowds of Missourians crossed the border and voted slavery into existence, abolition Kansas refused to recognize the authority of the elected Bogus Legislature as a proslavery government backed by the force of federal law. A particular legal time of Bleeding Kansas emerged, as military, federal, territorial, and state legal rituals existed alongside the people's procedures of arrest, imprisonment, and execution. This chaotic legal arrangement was the result of the region's transition from Indian Territory to Kansas Territory, when the law of popular sovereignty (the people's right to vote slavery in or out of existence) was mapped onto the colonial structure of squatter sovereignty, a prior legal arrangement that gave certain self-enforced rights to "illegal" white residents in the Indian Territory. In the context of these multiple and overlapping legal arrangements, the idea of abolition justice as the work of the people was condemned and then forgotten by the time Curry painted the mural at the Kansas capitol.

When Curry created the mural between 1937 and 1942 as part of a New Deal project to remember the fading rural landscapes of the heartland, his work was being shaped by memories of a war that was seen no longer as an irrepressible struggle but as a needlessly provoked and fratricidal tragedy. The war that was depicted in Tragic Prelude was part of a changing historical narrative that recast 
and even condemned abolitionists for having taken the law into their own hands. Curry attempted to resurrect the memory of John Brown's justice in order to show that the Civil War was the fault of extremists on both sides, but his middle-ground vision and his massive tribute on the capitol walls embarrassed the citizens of Kansas. Preferring to forget John Brown, Kansans in the 1930s and 1940 s criticized Curry for focusing only on "the worst" of Kansas. The Kansas Women's Council publicly condemned Curry's display of the "freaks" who "did not follow legal procedure" and the mural's erasure of law-abiding Kansas. ${ }^{1}$ Curry's representation of the extralegal forms of justice that haunted the landscape was condemned in a moment of forgetting, as Kansas refashioned its reputation for fanaticism into a reputation for modern governance that made it worthy of the first national prison. ${ }^{2}$

The idea of Leavenworth Penitentiary arrived in what is now called Kansas thirty years into the afterlife of a civil war over slavery at the Kansas-Missouri border. The idea of Leavenworth was a response to the legal time of Bleeding Kansas, where competing claims to state authority by abolitionist, free labor, and proslavery political imaginaries were already ideas about punishment. Leavenworth was a claim to federal jurisdiction in a place that had already developed local customary traditions of law as the work of the people. Leavenworth tried to mark the end of popular sovereignty, the specific form of white political participation crafted by Congress in order to expand slavery into Kansas Territory, as it replaced the earlier regime of squatter sovereignty, which governed trespassing white settlers who made soon-to-be-legalized claims to the land. It was this strange combination of colonial and domestic law that made it possible for abolition Kansas to turn law against itself and to create an extralegal customary tradition in which the practice of justice was simultaneously the practice of freedom. As a symbol of state power, Leavenworth removed the work of justice from the people and secured it for a state that hunted, captured, and eventually killed John Brown for imagining a different kind of justice.

While the federal prison's insertion into the landscape brought a federal politics of law and order to Kansas, it also intervened in an already existing political culture and custom that was lived as law and that remained a powerful part of daily life long after the centralization of state power. The idea of Leavenworth Penitentiary represented the victory of legal violence over the kinds of "public" justice that the state condemned as the work of the "mob," practices that were used by both abolitionist movements and proslavery forces to institute competing forms of justice. This meant that what became Kansas complemented the already existing legal order (one in which justice was a popular practice) but inverted the promise of abolition by encouraging "the people" to practice justice on behalf of the state. It encouraged community participation in state justice rituals, including collective hunts for fugitives escaped from the prison and gruesome spectacles of execution that made citizens into witnesses. Kansas statehood and the federal law-and-order 
project that supported it transformed the abolitionist vision of popular sovereignty from the central participatory institution of daily life to a mechanism that encouraged the people to do justice on behalf of the state. In taking justice from the people, Leavenworth both interrupted and continued the racial life of punishment that had brought Bleeding Kansas to war. Because the federal prison inherited already existing justice practices that were lived as a form of custom more powerful than law, Leavenworth marked the end of squatter and popular sovereignty but carried the legal time of Bleeding Kansas into the future of statehood.

This chapter is a study of the legal culture that both preceded and interpenetrated the order of Leavenworth Penitentiary. It examines the prison's deep and abiding connections to slavery in a place that went to war to refuse it and then welcomed the prison as a symbol of statehood, forgetting at once their contradictions as congenital institutions and the meaning of Bleeding Kansas for the nation. The betrayal of abolition Kansas is a story about the meaning of justice and about how memories of the legal time of Bleeding Kansas might return abolition to its most important question: What does it mean to be free? How did the prison become wedded to peculiar forms of personhood that are now taken for granted as "citizenship," and how might the story of Bleeding Kansas and the particular moment of abolition it represents be used to recall a memory of freedom not defined by the prison? This chapter examines both how a place on the edges of law was brought "in line" with state control through the prison's racial project and how the disarticulation of law from justice in abolition Kansas could have created a future without mass incarceration. Telling the story of Bleeding Kansas as a story about the complex relationship between slavery, justice, and punishment, the chapter begins with an account of the colonial and territorial laws that legalized and regulated slavery in the region and then analyzes the competing sets of justice rituals that began with squatter and popular sovereignty and that remain embedded in the political and social life of a place like Leavenworth.

\section{THE WORK OF LAW AT THE KANSAS-MISSOURI}

\section{BORDER}

The story of Bleeding Kansas as a particular moment in the history of law begins with the origins of slavery and the system of regulation that developed in Missouri and then spilled over into Kansas as a remnant of overlapping colonial legal formations. Slavery was embedded in the legal framework of the region long before Kansas would adopt the Missouri Code. In the early 170os, French colonial law, alongside Spanish claims to the land, instituted both Black and Native slavery in Upper Louisiana with the 1724 Black Code. The Code Noir established punishments for both enslaved and manumitted persons who violated colonial laws, and it criminalized speaking out against slavery. ${ }^{3}$ When the Spanish assumed control of the region again in 1763, they prohibited Native slavery in Upper Louisiana by 1769 but did not repeal the Black Codes. The Spanish legal framework simply translated 
the French Code Noir into Spanish, overlaying the future of law in the region with the status of enslavement. When Spain sold the Louisiana Territory to France and then to the United States as the Louisiana Purchase in 1803, the new Missouri Territory was slow to implement its own legal structure and remained a part of the legal culture of colonial Louisiana. When Missouri became a state in 1820 , it incorporated the laws of slavery from the state of Virginia as its legal foundation. ${ }^{4}$

As a descendant of Louisiana's Black Code and Virginia state law, Missouri Territory became a US state through the Compromise of 1820 , which gave Missouri to the South and Maine to the free states. Missouri's location disrupted the original idea of the Mason-Dixon Line because it permitted no slavery north of Missouri's southern border. When the Compromise of 1820 produced Missouri as a southern state above the line, Missouri was a slave state that intruded into the North. ${ }^{5}$ Missouri's jurisprudence of slavery was rooted in its relationship to prisons and criminal law. The prison was built to regulate slavery and criminalize abolition, which it did through a series of provisions for the punishment of "larceny." ${ }^{\text {Like }}$ other states with relatively large Black populations, Missouri used the relationship between prisons and slavery to develop racialized mechanisms of control for both free and enslaved Black people that included licensure, spatial regulation, and criminal law.

In the context of its peculiar political geography, larceny law in Missouri was institutionalized as an antiabolitionist practice, and the Missouri State Penitentiary routinely punished abolitionists. Missouri prisoners included slaves who ran away and "stole" their own bodies, white abolitionists who accompanied the enslaved into freedom, and white slave hunters who kidnapped slaves to sell in the Deep South markets, thereby depriving other white people of their "property." The Missouri Penitentiary, built at Jefferson City in 1830 as the largest state prison west of the Mississippi, was often referred to as "the slaveholder's prison" because it housed forty-two Black and white abolitionists from the 1830 os until the 1860 s and because it was used by private slaveholders to preemptively detain slaves who might escape. When the white abolitionist George Thompson was imprisoned in 1841, he documented the status of an unnamed Black prisoner who was brought to the penitentiary because of a "suspicion on the part of the master that he would run away." 7 In 1835, a new criminal code set a minimum prison sentence of two years for stealing slaves and required Black people to register in local precincts to receive freedom licenses. ${ }^{8}$ Unlicensed freedom was a criminal offense for Black residents in the state of Missouri.

Missouri consolidated the power of its proslavery legal architecture with the successful prosecution of the white abolitionists Alanson Work, James Burr, and George Thompson in a case that illustrated the legal contradictions of slave law and its relationship to punishment. The three Illinois missionaries had crossed into Missouri for a "tour of mercy." When they enticed a group of slaves to run away, the group they approached assumed they were slave traders and alerted authorities, who arrested, tried, and incarcerated Work, Burr, and Thompson. ${ }^{9}$ 
Although Missouri's initial strategy was to try the abolitionists for larceny, the defense successfully argued that abolition could not constitute larceny because larceny required an intention to convert stolen property into personal property. When the state reduced the charges to stealing, attempting to steal, and intending to attempt to steal, the men were convicted and given twelve-year sentences in the penitentiary.

The criminal case of Work, Burr, and Thompson exposed the complicated relationship between law and custom as it emerged in Missouri, a state with two competing and complementary justice rituals-one being the set of state practices that relied on the county jail and the state prison (which was monitored and occasionally taken over by vigilante mobs) and the other being the customary and binding obligation to refuse state involvement in matters of citizen justice. Mark Twain's father served on the jury that convicted Work, Burr, and Thompson, and these competing conceptions of legal authority became the basis of Twain's novel Pudd'nhead Wilson, published in $1894 .{ }^{10}$ In Missouri, custom often required fighting a duel rather than appealing to the local courts, so "Pistols, dirks, and daggers were everywhere in evidence" and were used in a system of quick justice in which "the trial was held immediately ... [and] the jury [was] composed of frontiersmen ... free from legal niceties." therefore a trial for Missouri's emergent system of criminal justice; it was widely known that if the court failed to return a harsh sentence the defendants would be taken from the courthouse by a mob and hanged. According to Thompson's memoir, "The infuriated mob, with their faces all Blackened, had prepared the gallows, and even the ropes." ${ }^{\prime 2}$ When their sentences were announced, the courtroom erupted with declarations that the citizens had "got clear of mobbing them." ${ }^{13}$ The convictions demonstrated the security of the state's claim to punishment, but the culture of extralegal authority still demanded that the state appoint a group of one hundred men to safely transport the prisoners to the state penitentiary.14 Despite the victory of law, the Missouri legislature passed an 1845 statute requiring a minimum prison sentence of seven years for grand larceny, for "enticing, decoying, or carrying away" a slave and for "aiding in enticing, decoying, or carrying away a slave." ${ }^{15}$ By 1855, Missouri law prohibited altogether the entry of enslaved people "with the intent to effect freedom." ${ }^{16}$

Against the backdrop of Missouri law as a specific jurisprudence of slavery and prisons, Kansas law developed as a contested and palimpsestic terrain that gradually accumulated ideas about the meaning of law and order as a proslavery practice. ${ }^{17}$ These ideas came from the already existing but shifting political geographies of Indian Territory in 1825, Kansas Territory in 1854, and Kansas State in 1861. The legal transitions between territorial and state governance occurred through the claims of squatter sovereignty, a white settler colonial framework of possession that intertwined the law of slavery and punishment in what squatters called a "region beyant the law." ${ }^{18}$ In Indian Territory, a space adjacent to but not 
necessarily subject to Missouri law, customary justice rituals spilled over the border from Missouri into Kansas as illegal squatters made imaginary land claims in the region. These extralegal practices became part of the economic and political landscape of Kansas Territory as settlers claimed the right to govern themselves through the squatter association, the vigilance committee, and the impromptu court in improvised but practiced customary rituals.

In the absence of laws regulating the legal status of whites in Indian Territory, the squatter associations enforced rights in a Kansas Territory that did not yet exist. Acting collectively to establish a set of imagined rights, squatter associations formalized illegal land claims and punished those who failed to recognize the group's authority in disputes. Disagreements over the boundaries of these illegal land claims were routine, in part because the claims were often inscribed in pencil on the trees: "I claim 160 acres, of which this is the center stake." ${ }^{19}$ The squatter associations established rules for making claims, required that members build the foundation of a cabin or pitch a tent within thirty days, and expelled "intruders" who violated local customs. ${ }^{20}$ The enforcements complicated the relationship between legal and illegal land claims, so that anyone occupying land within a half mile of an already protected claim would be expelled from the region. The associations formed specialized committees to protect illegal settlements on reservation lands if the settler could demonstrate that he was "deterred from commencing his cabin, or otherwise improving his claim, on the ground that it was a violation of the law, but ha[d] in all respects complied with the ... resolution." ${ }^{21}$ Before the actual territorialization of Kansas in 1854, squatter associations claimed the right to police over six hundred illegal land claims, and it was through the power of policing that squatter sovereignty became a legal imaginary. ${ }^{22}$

When Kansas was territorialized, the right to practice these rituals of justice became enfolded into the ideological architecture of abolition Kansas because of the doctrine of popular sovereignty. In Kansas, popular sovereignty was a legal arrangement that enabled abolitionist and proslavery regimes of justice to exercise competing claims to the work of "democratic" law and to create contradictory understandings of justice that would eventually be reunited by the power of the prison. When the Kansas-Nebraska Act of 1854 carved Kansas Territory from Indian Territory and incorporated the region into US law, the law required that "the people" of Kansas Territory would decide whether slavery would be legal within its borders. The doctrine of popular sovereignty established the power of the franchise to determine whether slavery was legal or illegal in the Territorythe people were to "form and regulate their domestic institutions in their own way, subject only to the Constitution of the United States." 23 Popular sovereignty, as a legal idea, rearranged possibilities for the federal regulation of slavery by ending its containment by coordinate boundary, therefore opening the possibility of slavery's legalization everywhere. Because popular sovereignty was to determine the outcome of the first territorial election, proslavery and antislavery groups rushed 
to Kansas, both self-identified as "the Democracy." ${ }^{24}$ In the transition from Indian Territory to Kansas Territory in 1854 and up until the first contested territorial election in 1855, "the Democracies" became unseated sources of power that created competing legal imaginaries of slavery and freedom.

Against the backdrop of a territorial civil war over slavery, the various sides developed localized rituals of justice. It was the custom of the proslavery vigilance committees to give "a horse thief, robber, or homicide a fair trial" but to hang "a negro thief or Abolitionist without judge or jury." ${ }^{25}$ Nearly ten thousand Missourians joined "self-protection" societies in the early 1850 os and traveled from Missouri into Kansas to "establish the institution" of slavery. ${ }^{26}$ In Leavenworth, a squatter association named "the Self-Defensives" criminalized teaching Black people to read and arranged extralegal rituals for those "waited on by a committee and decidedly ordered to leave without any ifs or ands." ${ }^{27}$ The Self-Defensives criminalized the practice of law by abolitionists in Leavenworth and harassed antislavery lawyers through their Missouri newspaper, the Platte Argus: it asked on the front page "whether there was a true friend of 'the goose" in all of Leavenworth" ("the goose question" referred colloquially to a proslavery stance). ${ }^{28}$ In response to the taunts of the Platte Argus editors, the Leavenworth Herald demonstrated its firmness on "the goose question" by enticing an antislavery lawyer, William Phillips, across the river into Missouri, where he was stripped, shaved, tarred, and feathered- "carried astride a rail, and mockingly sold ... on the charge of expressing sentiments so as 'to disturb the domestic relation of the people'-that is, interfere with slavery." ${ }^{29}$ An unidentified Black man was "brought forward and commanded to sell Phillips at auction: 'How much, gentlemen, for a full-blooded abolitionist, dyed in [the] wool, tar and feathers, and all?" "3o

These rituals of justice developed deep roots in the culture of law, as both proslavery and antislavery territorial citizens arranged impromptu performances at the scenes of criminal offenses. Even in antislavery jurisdictions, the absence of state-made law authorized local citizens to stage the roles of judge, jury, and executioner in customs more powerful than law. Because these local justice committees are often subsumed within the study of spontaneous lynch mobs, the works of justice committees have often been described as chaotic and apolitical events rather than staged and rehearsed claims to the work of law. Although the vigilance committees of the squatter associations were sometimes popularly referred to as lynch courts, this practice of justice was also distinct from the practices of lynching that were carried out in campaigns of racial terror throughout the nineteenth and twentieth centuries. Instead of targeting Black citizens, the rule of the lynch courts in Kansas Territory was a form of white self-regulation administered as though it were a fully legal institution. ${ }^{31}$ The cultural force of Black lynching as it developed within and beyond US law was a different instantiation of the practice. The antilynching activist James Weldon Johnson, referring to the 4,015 acts of 
white mob violence against Black people between 1885 and 1922, distinguished the lynch courts that "accompanied the border troubles ... especially on the dark and bloody soil of Kansas," from "the recrudescence of lynching, in its present form, [which] dates from the period of Reconstruction." ${ }^{2}$

Although justice committees were distinct from lynching as a postwar regime of terror, the popular rituals that emerged from the doctrines of squatter and popular sovereignty are central rather than marginal to the history of law and legal thinking; they are institutions central to the formation and development of US law. As part of the tradition of US law, "frontier justice" emerged to regulate life on the edges of US jurisdiction, in places where the sentences handed down by justice committees were respected as though they were fully legal institutions. In interviews conducted after statehood, settlers reported that even death sentences from "these committees were seldom considered illegal." ${ }_{33}$ In Coffey County, for example, "A mob held trial and asked those in favor of death to pass to the right of [a] building and those against to the left. Nine-tenths went to the right." ${ }^{34}$ This "legal work" became such a routine part of the political landscape that the custom, when reported by local newspapers at all, often received the space of a simple sentence: "A gentleman from Franklin County said eleven horses were stolen, six men arrested, two shot, two hung and two dismissed," or "It is rumored that . . . a horse thief had been caught and hung." ${ }^{35}$ Invested with the force of custom, justice committees were accompanied by competing legal imaginaries of slavery and freedom that aligned with two competing forms of governance. In creating dueling proslavery and abolitionist governments in the same territory, the border war led to regimes of punishment that shaped the future of Kansas and the nation.

\section{BLEEDING KANSAS, CIVIL WAR, AND THE FORMATION OF JUSTICE RITUALS}

When popular sovereignty put slavery to the vote on March 30, 1855, invading Missourians voted slavery into existence in almost every township on the border, obtaining 6,320 votes in a place with only 831 legal voters. The national newspapers immediately reported that Kansas had proven herself "S.G.Q." ("sound on the goose question") and boasted that Kansas was now "peculiarly fitted for slave labor." ${ }^{36}$ The local proslavery newspapers reported that the Missourians, certain of their victory, had come with a live goose displayed-"a pole surmounted by the animal alive and squawking." ${ }^{37}$ The national experiment with popular sovereignty in Kansas resulted in the election of the Bogus Legislature, which tried to build a slave state in Kansas.

Despite the election of a territorial government, no formal institutions existed for four months until the fall of 1855 , when "justices and sheriffs were appointed under the bogus territorial laws; they were not recognized by the settlers, and did no business." ${ }^{38}$ During this time of uncertainty, the legal arm of the proslavery territorial 
government was often found playing poker at a cabin near the proslavery capital of Lecompton: "Judge Cato was an Alabamian, and always said 'de Cote' for 'the court' and sometimes ordered the sheriff to adjourn 'de Cote' until it could get a drink, which it then proceeded to do from a saloon opposite the court-room." ${ }^{39}$ Even after the formal appointment of a territorial governor, he sat, with little authority, at Fort Leavenworth, with only "a few chairs, a writing table, some boxes filled with books and covered with newspapers for seating visitors, a letter press, a stove, [and] other rude contrivances." 40 The region was, according to early settlers, "practically without law and legal machinery, aside from the territorial judges and marshal appointed by the president" between 1854 and $1858 .{ }^{41}$ Because the squatter courts were "as much respected and as effective as the government courts," they continued to regulate crime and punishment in the region: "There were but few offenses by resident citizens, and these were promptly and impartially dealt with by the assembled citizens of the neighborhood, without calling upon the bogus officials." ${ }^{42}$

The state-making project of a proslavery Kansas began the following year with the wholesale copying of the Missouri legal code into Kansas law. Incorporating slavery and its system of punishment, the Kansas Black Law was designed to make Kansas an extension of Missouri and to punish Black and white abolitionists beyond what was prescribed in the Fugitive Slave Act of 1850 . What federal slave laws punished with one or two years of imprisonment, Kansas now punished with death. It was a capital offense to rebel against slavery (to conduct, aid, advise, or induce rebellion) and to carry away or aid in the carrying away of a slave from Kansas Territory. The Act to Punish Offences against Slave Property banned "statements, arguments, opinions, sentiment, doctrine, advice or innuendo, calculated to produce a disorderly, dangerous disaffection among the slaves." 43 Speaking against slavery was punished by five years of hard labor, and any verbal or written denial of "the right of persons to hold slaves in the Territory" was punished with two years of hard labor. Having secured the right of slavery in the Territory, proslavery citizens and Missourians celebrated the speed with which Kansas joined the South, even as abolition Kansas pledged to live as if the election had not taken place. In refusing to acknowledge the authority of law, the abolition Kansas that John Brown joined developed its own practices of justice, and the state's response led to the prisonization of Kansas.

The Kansas slave laws fashioned a certain relationship between the unfreedom of slavery and the unfreedom of punishment in the absence of a state prison. The government of Kansas, as it was directed by the government of Missouri, drew the practice of imprisoning abolition into its newly formed territorial government. The Black Law built slave ownership into the very fabric of civic participation. Making support for slavery a requirement for participation in governance, the law required Kansas jurors to openly "admit the right to hold slaves in this Territory" as a condition of service. White citizens could vote and practice law only if they had never been convicted of violating the federal fugitive slave laws and 
if they swore an "oath or affirmation" to pursue fugitive slaves in the territory. Enfolding a belief in the legality of slavery into the very requirements of suffrage and civic duty, proslavery squatter associations declared that the code of Kansas was "more efficient to protect slave property than any state in the Union." ${ }^{4}$ By February of 1855, the first official territorial census in Kansas recorded 151 free Black people and 193 enslaved. ${ }^{45}$

These competing claims to legal and cultural authority between 1855 and 1857 meant that slavery simultaneously existed and did not exist. Slaveholders believed that if they brought enough slaves into the territory they could overcome the freestate refusal to recognize their claims of ownership. Because the white proslavery citizenry relied on the presence of black bodies as an indication of slavery's legal status, the bills of sale for Mary Davis, Anne Clarke, Buck Scott, Tom Bourn, Bob Skaggs, Liza, Lizzie, Judy, Nancy, Cely, Patsy, and Martha remain scattered in the records and archives. The bill of sale for Martha, written by Thomas Johnson, namesake of Johnson County, guarantees that she was "sound in body and mind and a slave for life and free from all claims." ${ }^{46}$ Despite the complicated presence of slavery in Kansas, the older settlers were shocked by the speed at which the memory of slavery was erased from Kansas's history. In interviews conducted well after statehood, C.E. Cory reported that in the 189os, he "called upon the venerable Dr. J.N.O.P. Wood at Wichita, a well-known opponent of the free-state movement, and compared notes on ... personal knowledge of slaves in Kansas, and . . . counted over 400 - and quit." ${ }^{47}$ Because of the presence of the Underground Railroad in northeastern Kansas, records also indicate that "very few of the small number [of whites] who came from the south dare[d] to bring slaves with them." ${ }^{48}$ In 1859, J. Bowles wrote a letter to F. B. Sanborn, John Brown's biographer, detailing "the fact of nearly three hundred fugitives having passed through and received assistance from the abolitionists here at Lawrence." 49 The widespread disappearance of property into people at the Kansas-Missouri border created new terrains of justice that sometimes succeeded in pushing the practice of slavery back across the Missouri border. Slavery always pushed back.

The rebellion against the structure of slavery that began in abolition Kansas as both a place and a legal imaginary began with the self-emancipation of Black abolitionists at the Kansas-Missouri border and with the informal network of civic institutions that emerged to enforce these freedom claims. Operating beyond the course of law, civic associations and vigilance committees worked to enforce the status of Black freedom by imagining new forms of subjectivity and belonging. In antislavery towns along the border, Black freedom claims were rooted in a different kind of legal imaginary, one that authorized the formation of underground depots, escapes from the local jailhouses, and sometimes even the extralegal punishment of proslavery people. Because of the earliest efforts at self-emancipation in Missouri, the routine and yet unrecorded escapes across the border resulted in the exponential growth of the "freed" population in 
Kansas. Black abolition crossed the line as early as $1848 .^{50}$ In the proslavery town of Leavenworth, the free Black citizenry was limited to 14 people in 1855 but grew from 192 in 1860 to 2,400 by the end of the war. ${ }^{51}$ Black Kansas grew from 627 in 1860 to 12,527 in $1865 . .^{52}$ It was the beginning of a Black Exodus that continued into the 188 os and that Sojourner Truth called the "greatest movement of all time." ${ }^{33}$ People like H.C. Bruce "escaped" the prison of Missouri to freedom in Leavenworth in 1855 and recorded his experience in The New Man: TwentyNine Years a Slave, Twenty-Nine Years a Free Man. ${ }^{54}$ Benjamin "Pap" Singleton, Samuel Perry, and Henry Adams established all-Black towns like Nicodemus and Singleton's Colony and prompted a congressional investigation. ${ }^{55}$ During the legal time of slavery, the creation of a free Black Kansas was part of an idea about popular sovereignty and the law as a force only as powerful as the people's belief in that law. This meant that slavery could be made illegal if the people believed in its illegality.

Although abolition Kansas disbelieved in the legal fictions of slavery, the federal government actively supported the rights of slave owners. Proslavery federal laws were routinely enforced in Kansas, even though the Missouri courts had established in Rachel $v$. Walker (1836) that transportation to a free space was a willful act of emancipation..$^{56}$ The US government not only recognized the right of whites in Kansas to transport, use, and sell slaves within the state's borders but also sent US marshals to intervene in local spaces of freedom. In the abolition newspapers, including the Kansas Tribune of Lawrence, the people challenged the right of slave hunters and federal marshals to "come among them" in defiance of local law and in defiance of the home as property protected against illegal search and seizure. Handbills posted in Lawrence warned residents that US marshal Leonard Arms had arrived "into your midst for the avowed purpose of NEGRO HUNTING," and claimed the right to practice justice: "[Arms] is watching your houses, by his piratical minions, night and day, and will enter and search them for victims. KNOW YOUR RIGHTS and STAND TO THEM. He has no right to INVADE your CASTLES." ${ }^{7}$

Because the doctrine of popular sovereignty configured the law of slavery and the federal intrusions that supported it as a kind of foreign invasion, the continuing interventions by an occupying force emboldened an antislavery Kansas, who held a series of nineteen public meetings in 1855 and 1856 to condemn the fraudulent election and pledge to live as if it had not taken place..$^{58} \mathrm{John}$ Brown's sons were in attendance, and Brown himself participated in the convention at Big Springs in 1855. When the competing proslavery government passed the Kansas Black Laws, the Kansas Tribune announced "the day of our enslavement" as speaking out against the institution became a criminal offense. The antislavery newspaper, in a full-page repudiation staged in oversized letters, declared that despite "the law" the people of Kansas "do declare and assert . . . that persons have not the right to hold slaves in this Territory, and we will emblazon it upon our banner in letters so 
large and in language so plain that the infatuated invaders who elected the Kansas legislature as well as the corrupt and ignorant legislature itself can understand it, so that, if they cannot read, they may spell it out." ${ }^{9}$ Interpreting the enforcement of the Black Laws as an act of war that threatened to enslave all of Kansas, antislavery jurisdictions fought to expel federal fugitive slave hunters from the territory and to establish a separate structure of governance.

When the abolition movement elected its own legislature, it gave rise to the formal double governance of Bleeding Kansas-two systems of territorial law at war in the same space. The "free state" government convened under the constant threat of arrest and detention, as charges of treason became central to the territorial government's strategy of using law and punishment to end abolition Kansas. The territorial government sent the military from Fort Leavenworth to disperse the assembled free-state legislature in Topeka in 1856; the military commander followed his orders in disrupting the meeting but refused to dishonor the participants by disarming them. On May 10, 1856, after President Pierce recognized the authority of the Bogus Legislature in a speech before Congress, the proslavery government in Lecompton arrested the free-state government "from the governor down, and clapped them into prison." ${ }^{60}$ Governor Robinson spent the next four months at the Lecompton Jail, while one of John Brown's sons was detained in the local judge's house. ${ }^{61}$ On May 14, 1856, George W. Brown, editor of the Herald of Freedom, was arrested on charges of treason for refusing to recognize the territorial government. He was held by an "armed mob" that "c[a]me in the name of law, clothed with authority of the federal government." 62 Through these displays of federal power in the "local" and contested arena of justice, punishment formed the forgotten background of Bleeding Kansas. The adoption of the prison as a mode of punishing abolition Kansas was rooted in the violence of federal slave law.

With the backing of military soldiers, local judges, county sheriffs, and US senators, the violence of Bleeding Kansas became embedded in territorial law. Alongside the widespread, unpunished murders of abolitionists by public and private authorities, it was the punishment of Lawrence, as a representation of abolition Kansas, that moved John Brown to claim the right to practice law. On the twentyfirst of May, as the free-state government sat in the makeshift prisons of the proslavery government, a crowd of proslavery Missourians, backed by US marshals making mass arrests in the township, burned Lawrence, Kansas, to the ground. ${ }^{63}$ The "sacking" of Lawrence, which occurred in 1856, preceded the more famous 1863 Lawrence Massacre known as Quantrill's Raid. Enforcing the law against abolitionist speech, proslavery forces stationed a cannon on top of Mount Oread and with a force eight hundred strong destroyed the presses of the Herald of Freedom and the Kansas Free State Tribune. On the orders of the local judge, Samuel D. Lecompte, the Free State Hotel, an institution central to the work of the New England Emigrant Aid Society, was burned to the ground. The sheriff of Douglas 
County, Samuel Jones, who lived across the border in Missouri, reported that the punishment of abolition Kansas had marked the "happiest day" of his life. ${ }^{64}$ Jones and others celebrated this first invasion of Lawrence as marking the successful control of the citizenry, particularly since the residents of Lawrence did not resist. John Brown returned to Lawrence, sat among the smoldering remains of the Free State Hotel, and declared open war against slavery and the law.

Before morning, John Brown had committed what W.E. B. Du Bois called a "deed of retaliation from the free state side so bloody, relentless and cruel that it sent a shudder through all Kansas and Missouri, and aroused the nation." ${ }^{65}$ In what became known as the Pottawatomie Massacre, John Brown drew attention to the unpunished murders of abolitionists by visiting the enforcers of the Bogus Legislature in the middle of the night, and sentencing them to death in "the flash of an awful stroke." 66 John Brown's rehearsal of the long-standing ritual shocked the nation. It brought public attention to the question of whether war would decide the slavery question, and widespread condemnation of the methods of "John Brown's justice." ${ }^{67}$ His claim to the work of law and to self-defense was dismissed as "mob justice" by the proslavery ruffians, by the new free-state officials, and by the agents of the federal government, whose attempts to capture and kill John Brown in the years that followed only added to his mythic stature. What was perhaps most dangerous about Brown was that he reframed slavery not as a right but as a crime. Challenging the unpunished "crimes of this guilty land," Brown's theory of justice was beyond the state and beyond the law. ${ }^{68}$ Despite public condemnation of the "immorality" of the hatchet, Kansas knew by now that "something must be done." 69

Between the Pottawatomie killings and his death by hanging in 1859, John Brown defied the force of law in ways that captured the imagination of the nation. From Kansas, Brown escorted self-emancipating people 2,500 miles in the dead of winter, reaching Canada with twelve people and a child born on the second day. Unscathed by law, Brown's accompaniments were successful in spite of the slave hunters who were always trailing behind, in part because of his ability to move in and out of the territory unseen. According to local newspapers, Brown was dead one day and raiding Missouri plantations the next, "appearing and disappearing here and there-now startling men with the grim decision of his actions, now lost and hidden from public view." ${ }^{\circ}$ Brown and his travel companions outran and outfought their opponents even when outnumbered. Samuel Harper, who escaped slavery in Missouri and traveled with Brown to Canada, recalled that when their hiding place was surrounded by seventy-five slave hunters, "There was only 14 of us altogether, but the captain was a terror to them, and when he stepped out of the house and went for them the whole seventy-five of them started running." ${ }^{71}$ During Brown's return from Canada, the Kansas governor wired a federal marshal to "capture John Brown, dead or alive." The marshal responded: "If I try to capture John Brown it'll be dead, and I'll be the one that'll be dead." 72 The failure of the law to punish John Brown's justice became a symbol of the power of abolition Kansas, 
as an idea that could not be burned, brutalized, or imprisoned out of existence.

The border war became, as Du Bois would later argue, a time when the South "fought to enslave all territory of the Union," and a place where slavery and abolition "met in Kansas, and in Kansas civil war began."73 Against the backdrop of John Brown's justice, state and federal courts soon changed the methods by which slavery was extended into a territory. Missouri had become the center of the comity question, as Dred Scott v. Sandford wound its way through the state's courts and arrived at the Supreme Court in 1857. The Missouri case restructured the legal status of slavery for the nation by overturning the earlier Missouri case of Rachel v. Walker (1836), which determined that relocation to a free space was a willful act of emancipation by the owner. The Court ruled that Dred Scott and his wife Harriet were not free by virtue of having been taken from Missouri to Illinois, since Missourians had no duty to recognize Illinois law: "No state is bound to carry into effect enactments [of another state] conceived in a spirit hostile to that which pervades her own laws." ${ }^{74}$ The political consequence of this ruling was that slavery was legalized everywhere. It ended the practice of recognizing a political geography of freedom, and it attached slavery as a legal status to the body of the slave. ${ }^{75}$ Once hinged to the body, the struggle over slavery and the enforcements of freedom at the Kansas-Missouri border were no longer guaranteed.

As the national legalization of slavery that occurred with Dred Scott in 1857 pushed abolition's line toward Canada, the struggle over the power to punish became central to the struggle over slavery. As being Black and being free became a contradiction that was etched onto the body, even those with freedom papers became targets of public and private forces, and attempts at relocation north were now considered crimes. In January of 1859, when "fugitive hunters" targeted people known to be free within the city of Lawrence, thirteen chose to leave the township and head north: "All had their freedom papers, except for two, Wilson Hayes and Charles Smith, who had worked as cooks at the Eldridge House and were known to be free men." ${ }^{76}$ Accompanied by the white abolitionist John Doy and his son, the group was apprehended and arrested nearly twenty miles outside of Lawrence near Oskaloosa, Kansas. Thirteen free Black people were sold into slavery under the authority of both public and private jurisdiction, with the exception of an unnamed man, who was sent to the Platte City Jail, where he soon escaped by "burning out the bars from the windows." 77 Letters written by those who aided him, including Ephraim Nute, reveal that in making his escape, he

walked 10 miles to the Missouri River and crossed on the floating cakes of ice; got $1^{\text {st }}$ on to an island or sand-bar in the middle of the river where he spent two days and nights hid in the young cottonwoods; thence again over the running ice to the Kansas side and walked the 35 or 40 miles to [Lawrence] in one night.... We have him now hid and are to day making arrangements to have him set forward tomorrow 30 miles to another depot. I think they will not be taken again without bloodshed. ${ }^{78}$ 
His departure north occurred when, according to those who hid him, he was transported "in a coach from Leavenworth disguised in female attire. We kept him 2 days. I then took him by night and afoot across lots through an 80 acre corn field in which the stalks are standing and to another hiding place from this he has in the same way been moved on from house to house until he is about 8 miles on his way and will be started in the small hours tomorrow morning for Canada." 79 As the peculiar institution became embedded in and enforced through the mechanisms of the jail and the prison, federal law formed the backdrop against which Kansas territorial law consolidated its power over the punishment of abolition.

The contested nature of law in the territory meant that even though the Doys had never left Kansas Territory, they were transported to the state of Missouri and held for trial in Platte City. They were charged under Missouri law for stealing slaves even though they accompanied free people, and were confined in a cell "made of boiler iron, eight feet square by seven feet high, with no ventilation except a small grating in the door." ${ }^{\circ 0}$ After two months in this "iron box," a change of venue moved the trial to St. Joseph, Missouri, where a heavily armed guard of mounted public citizens prevented their escape. ${ }^{81}$ In July, when the Doys were sentenced to five years in the Missouri State Penitentiary, another group of antislavery citizens traveled from Lawrence to refuse to recognize Missouri law. Breaking John Doy from the jailhouse, the "Immortal Ten" returned to Lawrence having refused to recognize the authority of Missouri or its penitentiary. ${ }^{82}$ The success of an impossible escape against a proslavery regime of punishment put the prison at the center of the war over freedom in Bleeding Kansas.

\section{THE PRISON REUNITES THE LEGAL IMAGINARIES OF SLAVERY AND FREEDOM}

Over the course of the next several years, "the trouble" in Kansas and the vastly different ideas about statehood, citizenship, and justice that constituted its legal time resulted in four applications for statehood. The federal government denied the first three applications for their ideas about state governance and finally admitted Kansas to the Union in 1861, when its proposed constitution conformed to the federal government's vision - a place that was subject to "law and order." ${ }^{83}$ As four state constitutional conventions defined not just what statehood would mean for Kansas but what Kansas would mean for statehood, the project of the prison became part of the commonsense governance of Kansas. Culminating in the Wyandotte Constitution, the process of state making combined a commitment to law and order with a vision of a people's prison. ${ }^{84}$ That project required that Kansas abandon its abolitionist visions, and as the free-state people transitioned into the Free State Party and entered the Union in 1861, the idea of a white Kansas betrayed and divided the free-state movement into abolition and "free-soil" factions. ${ }^{85}$ This division shifted the focus from the war over slavery toward the right of white Kansans 
to protect themselves from "foreign" invasions against their ballot boxes, whether by white Missourian invaders or Black fugitive "contraband." Du Bois described the Kansas compromise as resulting from a political coalition in which only "a few ... hated slavery, more . . . hated Negroes, and many . . hated slaves." ${ }^{86}$

Having betrayed its abolitionist past, Kansas disenfranchised Black citizens through a series of legislative actions, ballot initiatives, and legal decisions. The Kansas legislature voted in 1863 and 1866 to keep the word white in the state's constitution. In 1867 , white Kansas voters rejected a ballot initiative on Black suffrage. When the Fifteenth Amendment was ratified in 1870, the state courts immediately defied federal directives, and in 1871 the Kansas Supreme Court in Anthony v. Halderman approved the disenfranchisement of 150 Black voters for failing to properly demonstrate their residency in accordance with Leavenworth's city registration laws. Black residents of Leavenworth had challenged the Wyandotte Constitution's exclusions after a contested mayoral election, and the Kansas Supreme Court agreed with the defense that "the privilege or franchise of voting is only given to certain white persons." ${ }^{87}$ In Kansas, the word white was not removed from the state constitution until 1918.

The transformation of Kansas from a place of Black freedom to a place of Black exclusion had first been imagined at the failed 1855 and 1857 constitutional conventions. Although the wording was not included in the final draft of the Big Springs Constitution, the political platform excluded Black people from the state altogether: "The best interests of Kansas require a population of free white men." Rejected by Congress and President Pierce on the grounds that it would violate the property rights of slaveholders, the failed constitution nonetheless recorded the interconnectedness of prisons and slavery in its prohibition of slavery and its exception: "There shall be no slavery in this state, nor involuntary servitude, unless for the punishment of crime." 89 The failure of the first free-state constitution was followed by a proslavery convention that resulted in the proposed 1857 Lecompton Constitution. The Lecompton Constitution would have legalized slavery and restored the right of white property to a place "higher than any constitutional sanction ... the right of the owner of a slave to such slave and its increase is the same and as inviolable as the right of the owner of any property whatever." ${ }^{\circ}$ It would also have prohibited the legislature from regulating slavery at any point in the future, creating a structure of governance in which slavery would have become an unchangeable institution. The document was praised by President Buchanan but was ultimately defeated by Republicans in Congress.

When the promise of slavery failed to bring Kansas into the Union, the Free State Party responded with a convention held in Leavenworth in 1858, where party members drafted a document that outlawed slavery, enfranchised "every male citizen," and required the building of a state prison. ${ }^{91}$ Embedded in the very idea of a free-state Kansas, the prison became the foundation of the state-making project because it represented the authority of law. As an indicator of the possession of 
power, the prison served as the ultimate symbol of the right to do justice. While abolition Kansas had once fought and died over what it meant to be free, the state of Kansas would operate in the name of the people even as it claimed the right to imprison them. Supported largely by the free-state and free-soil political parties, the Leavenworth Constitution was the first to imagine a Kansas state prison, requiring that its location and its "directors and superintendents" be "elected by the people" in a "vote of the electors at large."92 The document's ratification was opposed by the old "border-ruffian element," which "remain[ed] in Leavenworth, and occasionally display[ed] itself." 93 The former members of the Bogus Legislature had reorganized themselves in support of the previously defeated Lecompton Constitution and in support of the principles of "Law and Order." The Law and Order Party, which met in Leavenworth as early as 1855, declared that "no man or set of men are at liberty to resist a law passed by a legislative body, legally organized, unless they choose by their actions to constitute themselves rebels and traitors, and take all the consequences that legitimately follow the failure of a revolution." 94 The party's ideas were described in relation to other proslavery civic organizations in the New York Times: "For some time past, it has been known that the Knights of the Golden Circle had revived their old organizations in town and county. Information gives their number in the city as about sixty and throughout the county at three hundred. They are composed principally of the old Border Ruffian element, with which we have always been pestered. All call themselves Democrats, and this faction hold the balance of power here. It is they who have the brains and money, and their votes carry elections. As a consequence, all officestrikers bow to their decision." 95

While the Free State Party and the Law and Order Party were divided and even at war over the question of slavery's future, the prison reunited the legal imaginaries of slavery and freedom. The idea of Kansas that finally brought it into the Union put the prison, as a symbol of law and order, at the center of its state-making project. When Kansas became a "free state" in 1861, the Wyandotte Constitution simply required that "a penitentiary . . . be established." ${ }^{6}$ The state immediately designed a prison that transferred the power of the people to the state. The location of the new state penitentiary, which was built in Leavenworth County by the architect Erasmus Carr, was selected because of the temporary use of the city jailhouse as a state prison and because of the prison's social importance in the new legal order of Kansas state. Leavenworth was selected because it "exerted a major influence in the councils of the new state of Kansas." ${ }^{97}$ By 1867, the prison was only a "temporary wooden stockade" measuring eighty-seven by thirty-six feet and housing one hundred prisoners who were "almost naked-clad in rags." 98 The result of one's imprisonment in this institution was a legal status of civil death: "A sentence of confinement and hard labor for a term less than life, suspends all civil rights of the person so sentenced during the term thereof . . . and a person sentenced to such confinement for life, shall thereafter be deemed civilly dead."99 


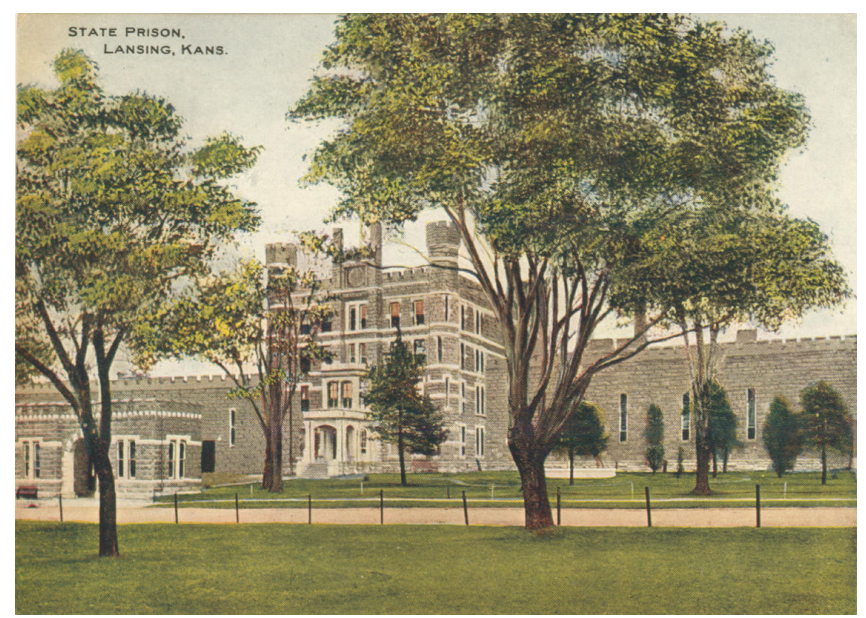

FIGURE 8. Postcard image, Kansas State Penitentiary, n.d.

This structure of civil death, which emerged from the Wyandotte conciliation, was a triumph of state power over and against the people's justice, and a betrayal of abolition Kansas. It inaugurated a system of governance that ended the practice of slavery but limited the franchise to "white male persons." ${ }^{100}$ Incorporating the racial framework of slavery into its afterlife, the prison reunited the legal imaginaries of slavery and freedom.

The prison at the end of the Mason-Dixon Line was, by 1875, indistinguishable from its proslavery counterpart in Missouri. Patterned after the prison in antislavery Illinois, its castellated architecture made it a symbol of northern reformative and industrial principles. Putting its 379 prisoners to work making wagons, shoes, furniture, harnesses, marble slabs, bricks, twine, and coal, Kansas was considered a model prison. As historian Blake McKelvey has noted, "Kansas stuck doggedly to what many had considered an overambitious program and was able to report in 1880 the completion of the entire prison structure. With 688 up-to-date cells patterned after those at Joliet it was, without a rival, the best prison west of the Mississippi." ${ }^{101}$ But prisoners in the institution published accounts of their experience, referring to the prison as The Kansas Inferno (1906) and A Kansas Hell (1890). ${ }^{102}$ John Reynolds, who spent time in both the Kansas and Missouri state prisons, even called the indistinguishable institutions The Twin Hells. ${ }^{103}$ The prison of Kansas was anchored in a routine state violence that was inflicted on the bodies of prisoners who were civilly dead-violence rooted in the use of the chain, the cuff, the iron horse, and the water crib, "a coffin-sized box that gradually filled with water while a strapped-down inmate struggled to keep from drowning." 104 Reuniting the legal imaginaries of slavery and freedom, the prison made use of popular sovereignty even as it secured for the state the practice of justice and the 
practice of law and order. This was an uneven and unstable security interrupted by the memories of border war and the legal time of Bleeding Kansas.

Although the prison that came with statehood was in some ways honored as the end of war, custom in many instances remained more powerful than law. The Kansas legislature found it necessary to protect the prison from the people's dissent. New laws in 1862 made it a crime to set fire to the new state prison or to rescue a prisoner from imprisonment or execution. ${ }^{105}$ These laws appeared necessary because the methods of the border war continued through the guise of popular justice. The proslavery element, for example, hanged John Guthrie for horse stealing in Bourbon County; observers described how he was punished "without authority or shadow of law and never [given] even a mock trial, as has generally been the case." ${ }^{106}$ Free-state vigilance committees also continued to hold court to punish proslavery forces. A party of free-state men arrested and hanged Russell Hinds after he returned a fugitive slave to Missouri; firsthand accounts suggest that, drawing on the tradition of civic justice, the party "quickly convened a court, sentenced and hanged him for this offense." ${ }^{107}$ In proslavery Atchison, in April of 1863, "A mob took possession of the jail and courthouse for a week; they held court and tried each prisoner, with four or five lynchings as the result." ${ }^{\prime 108}$ Between 1850 and 1930, there were 206 killings by nonstate actors assuming the work of law in the Territory and then state of Kansas. ${ }^{109}$

What was obscured by all the violence was that in the aftermath of slavery the war was really about the prison. What was also obscured was the federal government's role in fomenting that violence. When the Lawrence Massacre began on August 21, 1863, the Emancipation Proclamation had already been issued on January 1 . This meant that slaves in the Confederate states had gone free, but five hundred thousand remained legally bound in the southern states that did not formally secede. This meant that slavery still existed in Missouri until the governor issued a state proclamation in January of 1865 . In the space between slavery and freedom, federal troops in what had become the Border District (all of Kansas and western Missouri) began arresting the mothers and sisters of known Confederates in the region. The women were held in a former tavern in Kansas City, Missouri, that was repurposed as a prison..$^{110}$ With seventeen inside, the building collapsed and four women were killed. Others were permanently injured. The federal use of a prison on behalf of Bleeding Kansas led to retaliation in Lawrence. Quantrill's Raid was an early morning attack that killed nearly two hundred people in less than four hours. ${ }^{111}$ These events show how central the prison was to the war and its memory, and as moments in the history of the carceral state they illustrate what it meant to build a prison state.

The continuing struggle over punitive authority in the region was resolved through a process of centralization in which the state gained authority over matters of justice by preserving the old legal rituals in new forms and by including "the democracy" in the state practice of justice. Mobilizing the power of popular 
sovereignty on behalf of the state, the new legal regime drew on the old rituals of trial, imprisonment, and execution in order to consolidate state authority over practices of justice. Leavenworth's local papers described the military execution of John Shirley for robbery in a time of martial law as "one of the most exciting, soul-thrilling scenes ever witnessed" and as the "largest concourse of people [ever] assembled in Kansas." ${ }^{112}$ Shirley's hanging not only reinforced the spectacle of the procedure but consolidated the ritual influence of the military and martial law in Leavenworth. His execution had its beginning and end marked by the music of a military band-a "mournful dirge" for a death procession in which "silence pervaded the crowd," and a "lively air" as the body was taken down. ${ }^{13}$ As a celebration of a successful legal ritual, the military music that ended the ceremony also symbolized the triumph of federal law and order in a space that challenged state conceptualizations of justice. It was this triumphant practice that drew crowds of Kansans to witness the spectacles. When Carl Horne was hung in February of 1863 , "every crack or cranny of the high fence was soon sought out by two or three pairs of eyes, anxious to get a look at the [gallows]."114 By 1870, newspapers reported that executions were "besieged by crowds" so that "a stranger would have imagined a popular circus was about." ${ }^{15}$ As passive participants in the state's justice, citizens observed state and federal and military rituals and in doing so ultimately recognized the authority of the state through the new exclusions of participation.

These new legal rituals were distinguished by the citizen's changed relationship to the work of justice. In the older traditions, "the people" controlled the mechanisms of justice; they convened deliberative bodies and developed local rituals for carrying out sentences. But the new tradition distanced the citizen-audience from those who acted on behalf of the state. By 1870 , the identity of the executioner was routinely withheld from the public eye. In Leavenworth, the executioner was "enveloped in a Black domino surmounted by a Black hood."116 The crowds during hangings were "anxious to know who sprung the trap," but "the sharpest eyes failed to discover the identity of the masked instrument of the law's vengeance." ${ }^{117}$ Enshrouded in mystery, the rituals were part of a larger imaginary that specified roles for public and private actors in the spectacle of execution. In Leavenworth, it was customary for the masked executioner to utter the words "May God have mercy on your soul" and to release the trapdoor on the last word. ${ }^{118}$ Because the prisoner was hooded and his hands were secured behind him with a white handkerchief, the primary relationship that was produced and legitimated in the ceremony was between the executioner and the crowd. Unseen by the condemned, the charges were inscribed on a "grim document" that was tied with "Black crepe" and "handed to the sheriff at the proper time and ceremoniously unrolled." ${ }^{119}$

As the citizen became a different kind of legal participant, a direct observer who expected to read detailed accounts of executions in the morning papers, the public's perception of state authority was manufactured not only in the crowded rituals of state-imposed death but also in the recording and circulating 
of execution stories in local newspapers. ${ }^{120}$ As the act of reading about executions increasingly became part of the ritual, the press reported the details of death work in excruciating detail, evaluating for its audience the success of the new legal procedures. Allowing readers to relive the experience, the newspapers reported on the diligence of the authorities and the emotions of the condemned, along with the weather, the crowd, and the ritual silence of taking down the body. Reporting whether authorities seemed nervous or whether the death warrant was read in a "clear, steady voice," local newspapers emphasized the proper roles of the participants. ${ }^{121}$ Officials appeared confident in their own legal authority when the condemned appeared subdued and solemn in the final moments. John Shirley, who was executed during Leavenworth's martial law, was reported to have "ascended the terrible instrument of death" with confidence: his "step was firm, and not a muscle of his face showed the least indication of fear or faltering. He was not even pale." ${ }^{122}$ William Dickson in 1870 ascended the stairs of the gallows "more firmly," the paper noted, "than any of his escort." ${ }^{123}$

As state authority was consolidated over time by the widening of death's audience to include readers as witnesses, newspapers extended their coverage to include the minute details of the audience reaction. In 1870, Dickson's hanging in Leavenworth ended when he "hung without a struggle for twenty-five minutes" before a silent and stunned audience, while "a corps of physicians ... made examinations every half minute." ${ }^{124}$ The Leavenworth Daily Times published the information in chart form - “a resume of the dying man's pulse rate, taken every thirty seconds." ${ }^{25}$ The force of state death as cultural custom became such an important form of political participation (albeit a passive and even exclusionary form of participation) that the Leavenworth Daily Conservative celebrated punishment as a public duty, even as justice became both a state and a private practice: because of the burdens of the past, "a summary visitation of merited punishment has become a duty." ${ }^{126}$ While the Daily Conservative had once been one of the most ardently antislavery papers in the state, it now celebrated the punishment of its criminals: "Punishing criminals is one of our things, and we shall adhere to it!" 127

\section{THE MEANING OF LEAVENWORTH}

When Kansas stood against slavery in 1854, it abolished slavery but retained the legal status of the slave in its prisons. It could have been otherwise. Abolition Kansas might have refused to honor the state practice of the prison as it had refused to honor the legality of slavery. Instead, the military, state, and federal prisons of Kansas became monuments to law and order and a reconciliation that recalled the dream of abolition justice only as part of the shamed history of "mob rule." The idea of the prison was always at the center of the federal intervention in Bleeding Kansas-it emerged first in judges' homes turned into jails, in buildings that collapsed, and in tents pitched on the prairie. When the federal idea of law 
and order finally took the shape of a castle with bars, walls, and cages of steel after 1861, it failed to eliminate the power of custom. Emerging from this very specific place and time, the idea of Leavenworth was the culmination of a long attempt to wrest power from the people in the name of the people, and it secured that power through the inversions of an architecture that signified democracy.

Positioning itself as the answer to its own violence, the federal prison system took root in the afterlife of Bleeding Kansas, transforming a place that had rejected federal power into a place that embraced penal citizenship as a way of life. That process of prison building as state building through the terrain of culture is etched onto the landscape and honored as a form of law and order that now constitutes its very statehood. John Brown and "the freaks" who defied federal law to abolish slavery as a legal imaginary have been tucked away in the cemetery or the madhouse, or have even been condemned as early examples of "domestic terrorism." 128 When abolition Kansas is acknowledged, its power as a form of justice is often marginalized as "essentially a myth" because only a vocal "minority" believed in slavery's illegality or because the protection of white voting rights from outside invasion eventually became paramount. ${ }^{129}$ Others have suggested that the violence of Bleeding Kansas has been exaggerated on the grounds that there were "only" fifty-six "political killings" in Kansas Territory between 1854 and 1861, a counting that presumes that the lines between state and private violence and social and political crimes could ever truly be measured. ${ }^{130}$ It also fails to capture the chronology of a violence that continued beyond the Civil War, particularly since the second burning of Lawrence, which took nearly two hundred lives in a single morning, occurred in 1863 . Bleeding Kansas was a critical moment in a local war over the terms of democracy but also in the history of US law and the emergence of the carceral state.

The prison's central place in the legacy of Bleeding Kansas is now forgotten even in moments of its remembrance. When recalled by the major news networks during basketball games between the Kansas University Jayhawks and the Missouri University Tigers (both named after militia groups from Bleeding Kansas), sportscasters describe the popular rivalry as drama that goes "all the way back to the Civil War." The documentary film The Border War contains footage of a pregame celebration in which Jayhawks insult Missourians with signs that accuse them of being slave owners and racists, while Missouri fans warn that the game will mark Quantrill's Revenge. As sworn enemies, the Kansas Jayhawks and Missouri Tigers of the twenty-first century did not approve of a change in the annual event's official description from "Border War" to "Border Showdown" after 9/11, when it was decided that it was no longer appropriate to refer to intercollegiate sports as war. Former Kansas coach Don Fambrough remarked that "it's not a showdown, or a hoedown, it's a goddamn war. And they started it." ${ }^{131}$ Because the annual tradition was ended in 2012 after nearly one hundred years because of conference changes, the teams no longer engage in a rivalry that makes the nation 
remember. The political consequence is that Bleeding Kansas is no longer part of a national memory despite its relation to penal federalism but is reduced to local rituals like the annual reading of the names of Lawrence's dead. The prison's absence from these resurrections and burials means that the federal apparatus that overlaid and prosecuted the landscape of abolition justice is no longer understood as an invasion. When Kansas was taught through punishment to reject "mob justice" and embrace the federalization of crime and punishment, the federal prison's meaning in the context of that history was reduced to the forgotten rubble of a war punished by the turning of "the people's house" into the Big House. Despite the fading of the border war from public memory, abolition Kansas remains etched on the walls of the state capitol building. John Brown's body is present, but not his warning that the free state might be turned into the prison state: "On the eve of one of the greatest wars in history,.. .I fear slavery will triumph, and there will be an end of all aspirations for human freedom. For my part I drew my sword in Kansas when they attacked us, and I will never sheathe it until this war is over. Our best people do not understand the danger. They are besotted. They have compromised so long that they think principles of right and wrong have no more any power on this earth." ${ }^{132}$ Having been made to believe in institutions as sites of justice, the prison remained an artifact of slavery in the most radical of states on the slavery question. As part of the history of mass incarceration, the legal time of Bleeding Kansas led to the formation of the federal prison system and a cultural tradition of penal citizenship that normalized civil death and state violence. 